secure marketing arrangements.

There are many other aspects of this whole problem which, to the authors mind, point towards the fact that this country should increasingly associate itself with the Third World.

Lastly in this connection, it should be stated that although this country, in global terms, should see itself as a developing nation and should act accordingly, in the Southern African context, it is the other way round. In other words, the development role that this country will have to fulfil in our part of the world coincides perfectly with that of the developed or highly industrialized world. We can, therefore, expect that the same pressures that are being brought to bear on the Developed World from Third World countries will be launched at the RSA in the Southern African context.

The author is optimistic, however, that in regard to the more localized areas of concern, South Africa in recent years has gone through an intensified process of rethinking and re-evaluation of its development role in Southern Africa. Those parts of the development strategy that have already come to the fore, shows a striking resemblance to the development strategy proposed by the Third World. Probably the most important aspect of this strategy is that the main development thrust will have to come from a more acceptable regional spread of economic activities which will make it possible for the less developed regions to share in a greater part of the total market of primary and also manufactured goods of the Southern African region. South Africa, which, relative to these areas, is a capital surplus country, will of course have to supply the necessary funds and know-how to these countries not only for project finance, but also for overall development assistance. It has been mentioned that an important leg of the Third World strategy to acquire a more meaningful part of world economic development, is to group themselves into sub-regions that will be more effective in bargaining with developed nations. Again this is in line with the Southern African development strategy that is being pursued by our Government where considerably more emphasis is being put on the need for closer co-operation at the institutional level for the purpose of more effective regional development. Even the proposed establishment of a Southern African Development Bank is well in advance of the proposed new order of the glabal development strategy.

To conclude and summarize it can be said that from a strategic policy planning point of view, this country is already in the process of bracing itself for the rough ride in the economic world over the next decade or more. This country would still have to make a few difficult decisions on what its proper policy stance is going to be in order to handle effectively the global as well as the more localised development issues that will confront it.

\section{Recommendations of the first report of the inter-departmental committee of inquiry into certain specific pension matters}

\author{
W.B. Swanepoel
}

W.B. Swanepoel

Actuary, Office of the Registrar of Pension Funds

\section{Summary}

- In considering the quantum of a member's 'interest' in a Pension or Provident Fund, the Committee took as starting point the facts that this interest is -

* zero - at entry;

and the capitalized value of the full pension as stated in the rules of the Fund - at retirement;

- and proceeded by considering the best way in which to link these two points. The obvious choice for a final salary scheme with a pension factor of e.g. 1/60 is a formula of the type -

$$
v^{n-1} \frac{t}{60} S a_{6 s}^{\prime}
$$

where $\mathbf{v}^{n-1}=$ the discounting factor from retirement to date of calculation;

$\mathrm{t}=$ number of years' service to date of calculation;

$\mathrm{S} \quad=$ salary at date of calculation;

$a^{\prime}{ }_{65}=$ the value of an annuity of R1 per annum from retirement.

- The deliberations thus devolved upon the choice of two rates of interest, one for $v^{n-1}$ (i.e. before retirement) and one for $a^{\prime}{ }_{65}$ (i.e. after retirement). In evidence the Committee heard suggestions from major bodies of $5 \% / 5 \%$ and $7 \% / 7 \%$. The Committee rejected these (unmotivated) suggestions, i.e. on the following grounds:

\section{Post-rotirement}

- An artificially low rate (i.e. low relation to actual rates) implies an increasing annuity which is not envisaged in the rules of the Fund. This was considered unfair to Funds.

- An artificially low rate invites selection against the Fund in the shape of resignations just prior to retirement. This was considered both unfair and detrimental to Funds.

\section{Pre-retirement}

Although the Committee could not support a projection of salary as such, it was concerned about the effects of inflation on the calculated member's interest. Bearing in mind that the retirement benefit is framed in terms of final salary, that it is not proposed to project the salary, and that high actual rates of interest are brought about by inflationary economic conditions, it was thought unfair 
to members to discount their interest at a rate as high as (say) $9 \%$ if (say) six of that $9 \%$ is due to inflation. In brief, the Committee attempted to protect the real worth of the deferred pension based on current salary by letting the member have the benefit of 'excess inflationary interest'.

The Committee therefore recommended a rate pattern of $3 \% / 9 \%$.

- Since we have no idea how legislation in this regard will influence the future patterns of resignation, it is well-nigh impossible to assess the comparative financial effects of these suggestions. For what it is worth, however, my guess is that the $5 \% / 5 \%$ will be more expensive, and the $7 \% / 7 \%$ less expensive, than the recommended 3\%/9\%.

- Proceeding with the philosophy of deeming the benefit at retirement as deferred pay which gradually vests, one inevitably comes to the conclusion that this interest of the member in the Fund constitutes a minimum benefit at all times - be it upon resignation, dismissal, death, disablement, or liquidation of the Fund. Taking this philosophy to its logical conclusion, it means that this minimum interest becomes a legally enforcable promise, in contrast with the current contingent promise. The Committee also noted that, although a Fund can be considered an insurer or bank (with a restricted clientele), it was not at present subject to comparable disciplines. The Committee came to the conclusion that the philosophy of a contingent promise is no longer tenable in our modern day. Moreover, if we are to avoid the institution of a State pension scheme, the private sector must of necessity offer something more certain than a contingent promise, and finance the accruing liabilities in a way which offers more security than the employer's unilateral options -

- to dismiss a member shortly before retirement with nothing more than a refund of his own contributions;

- to reduce benefits retro-actively; or

- to liquidate the Fund without responsibility to settle $100 \mathrm{c}$ in the Rand.

- It should be emphasized that the 'Natural Actuarial Interest' discussed in the first two paragraphs is derived from whatever final retirement benefit the Fund saw fit to promise in its rules. Furthermore, the Fund is not exposed to an open-ended commitment, in that it remains free to reduce the pension promise - or, for that matter, to discontinue it entirely or to go into liquidation - in respect of service rendered after such a decision.

- Although the Natural Actuarial Interest presents the natural starting point for determining a member's interest in a Fund, the Committee further recommends that this be made subject to a minimum of a refund of the member's own contributions with 'reasonable' interest thereon - and that for this purpose the member should be deemed to have contributed at a minimum rate of $10 \%$ of salary. When one considers the various ways in which an employee's total package of reward (i.e. both immediate and deferred pay) can be made up, and keeping an eye on Part (c) of the Committee's term: of reference (i.e. pension provision for the popula. tion at large), it will be immediately apparent why we need the concept of a minimum deemed rate of contribution. It does, however, remain a fair question whether the specific rate of $10 \%$ is conclusively preferable to $7 \%, 12 \%$, or what have you.

- Regarding the 'Pension Provision Enclosure', the Committee took the view that the frozen nature of funds within this Enclosure does not necessarily im. ply that they repose in any specific Instrument, and argued that the undesirable possibility of a longterm trap be countered by allowing a high degree of mobility between the various Instruments within the Enclosure. Such mobility may well call for a more liquid investment stance, resulting in a concomitantly reduced performance; but the Committee thought the requirement of 6 months' notice might achieve the optimum arrangement. Counter-suggestions have been made that the interest-holder and the Instrument should be free to contract for longer notice periods in order to achieve better performance, and, it is felt that this merits serious investigation.

- In closing, the burden of Chapter 4 of the Report (which deals with the commutation of lump-sum benefits into annuities) can be summed up in the following statement:

'Pension provision deserves tax encouragement at least as favourable as the so-called 'Pure Fiscal Approach' - which amounts to a deferment of tax. This is a very valuable tax concession which can easily double and treble the final nett pension, but should be available only to Instruments which do in fact provide pensions. It is not in the public interest that the fiscus subsidize savings on this scale, if the final benefit can be drawn in one sum and dissipated or invested speculatively.'

It will be noted that the Committee did not find Provident Funds (or lump sums) as such undesirable as little as one can have complaints against someone hoarding (cut) diamonds under his mattress: what is at issue is the fiscal status of Provident Funds, and in effect the Committee thought lump sums under Provident Funds deserve as little or as much fiscal encouragement as diamond hoarding.

- There is a syndrome abroad - even among those who ought to know better - that 'free enterprise', 'free competition', etc. means -

- freedom to exploit the fiscus;

- freedom to make promises which can be broken at any time;

- freedom to pass on one's responsibilities to the next generation of taxpayers.

Sometimes the logic is so perverse, the difference between free enterprise and anarchy cannot be distinguished. We appeal to leaders and opinionmakers to approach the whole problem with care and circumspection, and with a mature sense of responsibility to all parties - including the next generation of taxpayers - rather than narrow, sectional, self-interest. 